\title{
Characterization and Comparison of Saprist and Fibrist Newfoundland Sphagnum Peat Soils
}

\author{
Emmanuel S. Asapo ${ }^{1,2 *}$, Cynthia A. Coles ${ }^{1}$ \\ ${ }^{1}$ Faculty of Engineering and Applied Science, Memorial University of Newfoundland, St. John's, Canada \\ ${ }^{2}$ Chemical and Polymer Engineering Department, Faculty of Engineering, Epe Campus, \\ Lagos State University, Lagos, Nigeria \\ Email: "esasapo@mun.ca
}

Received April 5, 2012; revised May 21, 2012; accepted June 9, 2012

\begin{abstract}
Saprist and fibrist sphagnum peat soils obtained from the same natural peat bog owned by Traverse Nurseries, Torbay, Newfoundland, Canada were characterized to study their potential for adsorbing metals. Both peat soils had a pH of 4.2. The saprist peat had the lower fiber content $(68.6 \%$ versus $75 \%)$, higher cation exchange capacity $(70 \mathrm{meq} / 100 \mathrm{~g}$ versus $45 \mathrm{meq} / 100 \mathrm{~g})$, higher moisture content ( $86 \%$ versus $82 \%$ ), higher organic matter content $(91 \%$ versus $84 \%)$, higher wet bulk density $\left(0.65 \mathrm{~g} / \mathrm{cm}^{3}\right.$ versus $\left.0.60 \mathrm{~g} / \mathrm{cm}^{3}\right)$ and higher dry bulk density $\left(0.28 \mathrm{~g} / \mathrm{cm}^{3}\right.$ versus $\left.0.20 \mathrm{~g} / \mathrm{cm}^{3}\right)$. A crystallography study showed that the saprist peat was completely amorphous and the metal content analysis showed high calcium and iron concentrations in both types of peat with higher values in the fibrist peat. Carboxylic acid, alcoholic hydroxyl, phenolic hydroxyl, amine and amide functional groups were present and these could be responsible for binding metal ions via ion exchange and or complexation reactions.
\end{abstract}

Keywords: XRD; SEM; FTIR; NMR; ICP-MS; Functional Groups

\section{Introduction}

Mining is a major contributor of soil and water pollution [1] and a high proportion of dissolved metals exist in areas surrounding mining sites [2] and have been analyzed in water samples long after the mines have been closed or abandoned [1]. Aqueous phase metals are highly mobile and aquatic life around any mine site could be perpetually endangered if improperly treated wastewaters are discharged.

Adsorption using low cost adsorbents such as agricultural wastes (orange skins, banana peels, [3]) saw dust [4], peat [5,6], clay and zeolites [7], is an effective alternative to precipitation, membrane technology and floatation for metal removal from wastewater. An adsorbent is "low cost" if it is readily available, requires minimal or no processing [8] and is inexpensive or of zero cost.

Peat soils are promising adsorbents for heavy metal removal $[5,6,9]$, easily harvested and are economical as can be seen from Table 1. Peat is partially fossilized plant matter that is formed in poorly oxygenated waters of marshes, bogs, and swamps where the rate of plant matterproduction and accumulation exceeds the rate of microbial oxidation [15]. Though peat is most common in the northern hemisphere, large deposits exist in Brazil,

${ }^{*}$ Corresponding author.
Indonesia and South Africa [16]. Peatlands or peat bogs record environmental and paleoenvironmental evolution and provide a reference for measuring past and present global climate change [17].

Since 1922 the von Post scale has been used to classify peat from poorly decomposed $(1 \mathrm{H})$ to completely decomposed $(10 \mathrm{H})$ and peat has also been classified as being highly decomposed (saprist), moderately decomposed (hemic) or poorly decomposed (fibrist) $[18,19]$.

Peat characterization has remained a difficult task since peat soils may form under a variety of conditions of vegetation and environment [20]. In the past characterization has provided details on the organic and inorganic compounds present in the peat, usually obtained through partial or complete destruction of the peat matrix, and details on the morphology and particle size. Previous studies have focused on the humic and fulvic acid fractions extracted from the peat [21-25] but the determination of the constituents or composition of peat, with minimal destruction is preferable and may be more realistic [26].

Poorly humified or fibrist peat (horticultural peat) has been well studied as an adsorbent for heavy metals [27-29] although the highly humified or saprist peat has not been studied to the same extent and the peat-metal bonding mechanisms have not been fully understood or 
Table 1. Relative cost of some adsorbent materials.

\begin{tabular}{|c|c|c|}
\hline Adsorbent material & Cost (US \$/kg) & Source \\
\hline Chitosan & 15.43 & {$[10]$} \\
\hline Activated Carbon & $\begin{array}{l}\sim 2.54 \\
\text { (production, quality and source dependent) }\end{array}$ & {$[11]$} \\
\hline Zeolites & $\begin{array}{l}0.03-0.14 \\
\text { (quality and end-use dependent) }\end{array}$ & [12] \\
\hline Clay & $\begin{array}{l}0.03-0.375 \\
\text { (quality and type dependent) }\end{array}$ & {$[13]$} \\
\hline Peat & $\begin{array}{c}0.024-0.052 \\
\text { (peat type and processing level dependent) }\end{array}$ & {$[14]$} \\
\hline
\end{tabular}

established [30], possibly due in part to the destructive characterization procedures employed. Saprist peat can be used as an agricultural enhancement for improving the water holding capacity of sandy soils [23] and possess a higher metal adsorptive capacity than the widely studied fibrist peat [31].

This paper describes and compares the properties of untreated saprist and fibrist peat soils from the same peat bog. Physico-chemical characterization of the two peat soils was undertaken using standard laboratory procedures and in addition, was supplemented with non-destructive characterization of the two peat soils employing five types of equipment including an X-Ray Diffractometer (XRD), a Scanning Electron Microscope (SEM), a Fourier Infrared Spectroscope (FTIR), a Solid State ${ }^{13}$ Carbon Nuclear Magnetic Resonance (NMR) and an Inductively Coupled Plasma-Mass Spectrometer (ICPMS). The saprist and fibrist peat soils are compared and the results are discussed in terms of the potential of the saprist peat to remove metals from wastewater, though metal removal studies were not a part of this research.

\section{Methods}

The two peat soils were obtained, courtesy of the Traverse Nursery, from a natural peat bog located between Torbay and Flat Rock (15 km north of St. John's), and an area, which is part of the largest peatland on the Avalon Peninsula of Newfoundland [32]. The peats were harvested at about $0.4 \mathrm{~m}$ depth (fibrist) and at about $1.6 \mathrm{~m}$ depth (saprist), transferred in flexi bags to the lab, weighed, spread on a plastic tray, and air dried at room temperature (about $23^{\circ} \mathrm{C}$ ) to remove about $70 \%$ of the original moisture content. Each was then homogenized by manually mixing after removing pebbles and undecomposed woody materials. The physico-chemical properties that could influence metal adsorption of the peat soils were determined by standard methods [33] as summarized in Table 2. All of the tests were conducted on the air-dried peat soils except for the wet bulk density tests that were conducted on the peat fresh from the field,
Table 2. Physico-chemical parameters of the saprist and fibristpeat soils.

\begin{tabular}{cccc}
\hline \multirow{2}{*}{ Parameter } & Method Used & \multicolumn{2}{c}{ Values } \\
\cline { 3 - 4 } & & Saprist & Fibrist \\
\hline Degree of decomposition & von Post & $8 \mathrm{H}$ & $3 \mathrm{H}$ \\
$\mathrm{pH}$ (in de-ionized water) & ASTM D2976-71 & 4.2 & 4.2 \\
Fiber content $(\%)$ & ASTM D1997-91 & 68.8 & 75 \\
$\begin{array}{c}\text { CEC at } 7.0 \mathrm{pH} \\
(\mathrm{meq} / 100 \mathrm{~g})\end{array}$ & $\begin{array}{c}\text { Calcium } \\
\text { acetate/chloride }\end{array}$ & 70 & 45 \\
$\begin{array}{c}\text { Moisture content }(\%) \\
\text { Organic matter }(\%)\end{array}$ & ASTM D2974-07A & 86 & 82 \\
AsTM content $(\%)$ & ASTM D2974-07A & 91 & 84 \\
Wet bulk density $\left(\mathrm{g} / \mathrm{cm}^{3}\right)$ & ASTM D4531-86 & 9 & 16 \\
Dry bulk density $\left(\mathrm{g} / \mathrm{cm}^{3}\right)$ & ASTM D4531-86 & 0.28 & 0.21 \\
\hline
\end{tabular}

${ }^{\mathrm{a}}$ Calcium acetate/chloride method [34].

and which was homogenized after removing the pebbles and woody materials. Grain size determination of the airdried peats was obtained by sieving triplicate dried peat samples over a series of mechanically stacked sieves.

To determine the total metallic contents of the airdried homogenized saprist and fibric peat soils, each soil was crushed in a mortar, acidified with $14.5 \mathrm{~N} \mathrm{HF}$ and 8 $\mathrm{N} \mathrm{HNO}_{3}$ and left on a hot plate for several days until completely digested so that all the organic components were released. Then $6 \mathrm{~N} \mathrm{HCl}$ and $8 \mathrm{~N} \mathrm{HNO}_{3}$ were added to dissolve the samples further and this step released the inorganic components. Finally $8 \mathrm{~N} \mathrm{HNO}_{3}$ was added and diluted with nano-pure water according to the rock dissolution procedure [33] in the Earth Sciences Department at Memorial University of Newfoundland (MUN) where the samples were finally analyzed with a model ELAN DRC-2 ICP-MS.

Micrographs of the peat pore orientation and surface morphology were obtained using the Hitachi S-570 SEM (Biology Department, MUN). To prepare the soil samples for each of the size fractions obtained from the dry granulometry test but excluding the dust fraction (Table 3) for the saprist and fibrist peat (for a total of twelve samples), each was spread over a carbon taped stud and coated with $550 \times$ Sputter Coater for gold operated at 20 $\mathrm{mA}$ in a vacuum of 0.2 mbar for 2.5 mins resulting in a $15 \mathrm{~nm}$ thick coating on the peat.

The mineral content was analyzed for each of the same twelve size fractions of the saprist and fibrist peat samples that micrographs had been taken of. Samples were packed on a vertically placed stud of the Rigaku Rotaflex D/Max 1400 rotating anode powdered XRD (Earth Sciences Department, MUN) with $\mathrm{Cu}-\mathrm{K} \alpha$ radiation source 
Table 3. Dry granulometry resultsfor the two peat types.

\begin{tabular}{cccc}
\hline \multirow{2}{*}{ Sieve No. } & Sieve size $(\mu \mathrm{m})$ & \multicolumn{2}{c}{ Average \% retained by weight } \\
\cline { 3 - 4 } & & Saprist & Fibrist \\
\hline 4 & 4750 & 13 & 15 \\
8 & 2000 & - & 19 \\
20 & 850 & 52 & - \\
40 & 425 & 15 & 45 \\
50 & 300 & 5 & - \\
60 & 250 & - & 9 \\
100 & 150 & 6 & 4 \\
200 & 75 & 3 & 6 \\
Smaller dust & & 6 & 2 \\
\hline
\end{tabular}

operated at $40 \mathrm{kV}$ and $100 \mathrm{~mA}$ from Rigaku/MSC-Japan equipped with an X-ray stream 2000 low temperature system. The spectra obtained were matched through the JADE data software (Earth Sciences Department, MUN).

The functional group content of the same twelve fractions of the saprist and fibrist peat soils that were analyzed with a SEM and an XRD was identified using the Bruker TENSOR 27 FTIR (Chemistry Department, MUN) equipped with a MIRacle ATR accessory coated with crystallized $\mathrm{ZnSe}$ with absorbance range from 4000 and $650 \mathrm{~cm}^{-1}$. A few grains of each air dried homogenized peat sample was placed on the pressure tip, compressed onto the sampling area at the center of the $\mathrm{ZnSe}$ crystal plate, and was scanned for one minute in transmission mode double sided forward/backward at a spectral resolution of four wavenumbers. The equipment incorporates a $\mathrm{KBr}$ beam splitter, aperture ( $6 \mathrm{~mm}$ setting) and detector. Solid state ${ }^{13} \mathrm{C}$ NMR of a peat samples were taken from fraction $<425 \mu \mathrm{m}$ to identify the dominant functional groups. The spectra were obtained at $298 \mathrm{~K}$ using a Bruker Avance II 600 spectrometer, equipped with a SB Bruker $3.2 \mathrm{~mm}$ MAS triple-tuned probe operating at $600.33 \mathrm{MHz}$ for $1 \mathrm{H}$ and $150.97 \mathrm{MHz}$ for ${ }^{13} \mathrm{C}$. Chemical shifts are referenced to tetramethylsilane (TMS) using adamantane as an intermediate standard for ${ }^{13} \mathrm{C}$. The samples were spun at $20 \mathrm{kHz}$ for ${ }^{13} \mathrm{C}$ NMR spectra. Crosspolarization spectra were collected with a HartmannHahn match at $62.5 \mathrm{kHz}$ and $100 \mathrm{kHz} 1 \mathrm{H}$ decoupling. The recycle delay was $2 \mathrm{~s}$. The contact time was $2000 \mathrm{~ms}$ for ${ }^{13} \mathrm{C}$ NMR.

\section{Results and Discussion}

\subsection{Physico-Chemical Properties}

The physico-chemical properties of the two peat types are summarized in Table 2. On the von Post scale of classification, the saprist peat was $8 \mathrm{H}$ while the fibrist peat was $3 \mathrm{H}$. Both peat samples were acidic and had relatively high fiber contents, with the fiber content being greater in the fibrist peat (as would be expected).

The cation exchange capacity (CEC) was $70 \mathrm{meq} / 100 \mathrm{~g}$ for the saprist peat compared to $45 \mathrm{meq} / 100$ for the fibrist peat. The higher CEC of the saprist peat suggests that it could be a better adsorbent for metal removal though it is the fibrist peat that has been the most widely tested as an adsorbent for metals. Both peats had high moisture holding capacities with the saprist peat having the higher value. Since CEC influences uptake of hydrated cations, CEC is also related to moisture holding capacity and so the results are reasonable.

The organic content was greater in the saprist peat, which can be attributed to the higher degree of decomposition [35], longer exposure to weathering (including mechanical activities such burrowing by worms, soil movement and coverage), and deeper zone of formation [20]. Consequently the ash or inorganic content was greater in the fibric peat (since the one test gives both the organic and inorganic fractions and their sum is the total material).

The bulk density (wet and dry) of the saprist peat was higher as this peat was dominated by more of the smaller particle size fractions (as shown in Table 2). This is also related to the greater water retaining capacity that the saprist peat exhibited as the smaller particles would contribute to a greater overall surface area.

The particle size distributions of the air-dried homogenized peat soils (in Table 3) are showing that only $13 \%$ of the saprist peat had particles $>2000 \mu \mathrm{m}$ whereas $34 \%$ of the fibric peat had particles $>2000 \mu \mathrm{m}$. Fractions $>2000 \mu \mathrm{m}$ in the fibrist peat were woody undecomposed materials. Fractions $<2000 \mu \mathrm{m}$ and $>850 \mu \mathrm{m}$ were mostly fibre of unidentifiable decomposing materials.

\subsection{Metal Content}

The average metal concentrations in each peat sample are presented in Table 4. Also detected at concentrations below $1 \mathrm{mg} / \mathrm{kg}$ were $\mathrm{As}, \mathrm{Co}$, and $\mathrm{Pb}$. Although the presence of these metals could be due to both natural and anthropogenic sources, the results show that these peat soils have a natural affinity for the detected metals with calcium and iron being the predominant metals.

\subsection{Surface Morphology}

The micrographs of the twelve peat fractions ranged in resolution from 150 times to 2200 times but the at 1000 times it was easiest to identify pores without damaging the structure so these micrographs are presented and the fractions $\leq 425 \mu \mathrm{m}$ gave the best images of the pores and 
Table 4. Metals detected by ICP-MS analysis of the two peat types.

\begin{tabular}{ccc}
\hline \multirow{2}{*}{ Metal } & \multicolumn{2}{c}{ Concentration $(\mathrm{mg} / \mathrm{kg})$} \\
\cline { 2 - 3 } & Saprist & Fibrist \\
\hline $\mathrm{Ca}$ & 2392 & 2743 \\
${ }^{54} \mathrm{Fe}$ & 1012 & 971 \\
$\mathrm{Ti}$ & 34 & 98 \\
$\mathrm{Zn}$ & 15 & 88 \\
$\mathrm{Sn}$ & 8 & 8 \\
$\mathrm{Mn}$ & 7 & 27 \\
${ }^{52} \mathrm{Cr}$ & 4 & $\mathrm{ND}^{\mathrm{a}}$ \\
$\mathrm{Ni}$ & 4 & 0.7 \\
$\mathrm{Cu}$ & 2 & 0.3 \\
${ }^{77} \mathrm{Se}$ & 1 & $\mathrm{ND}^{\mathrm{a}}$ \\
\hline
\end{tabular}

${ }^{a}$ not detected.

structure. Therefore the $\leq 425 \mu \mathrm{m}$ fractions are shown in Figures 1(a) (saprist peat) and (b) (fibrist peat).

While taking the SEM images it was observed that the pores were interlinked, collapsed and overlapped. For example on Figure 1(a), no single pore could be identified as each pore is also surrounded by a larger pore of similar shape so they are concentric pores but they are also slightly deformed due to compression. This pattern enhances the water holding capacity of the saprist peat and the small opening in Figure 1(a) would allow the passage of water and also the interaction of the pore walls with aqueous heavy metal ions. The wavy patterns in the bottom right corner of Figure 1(a) are the constantly overlapping pores. Each pore consists of a unique internal cellular structure depending on the parent materials.

Most of the pores in the fibrist peat (Figure 1(b)) to a large extent retain their original shape, and could have originated directly from the plant forming materials and a study [5] reported this pore structure to be cellular. The pore structure in the saprist peat could be resulting from the compressive forces and it has been reported [36] that greater decomposition reduced the pore fraction, smaller particles were more packed together, and the bulk density was increased. This was evident in this study as the fibrist peat had the smaller bulk density and moisture content (Table 2). With increasing decomposition, pore sizes become smaller and inseparable (powder-like) resulting in a compact peat matrix with a higher water holding capacity. The fibrist peat normally has a higher porosity, which makes it favoured in gardening and horticulture where fast percolation of water is needed.

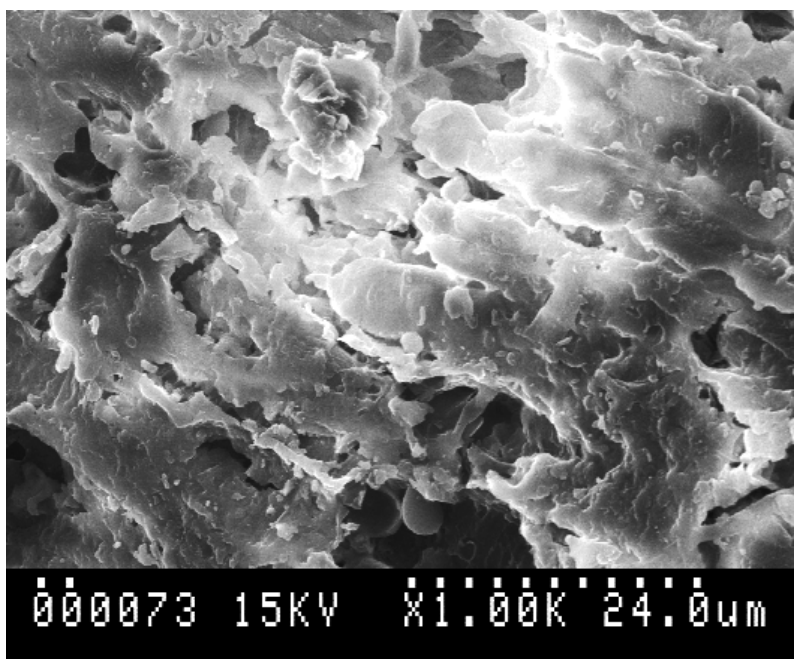

(a)

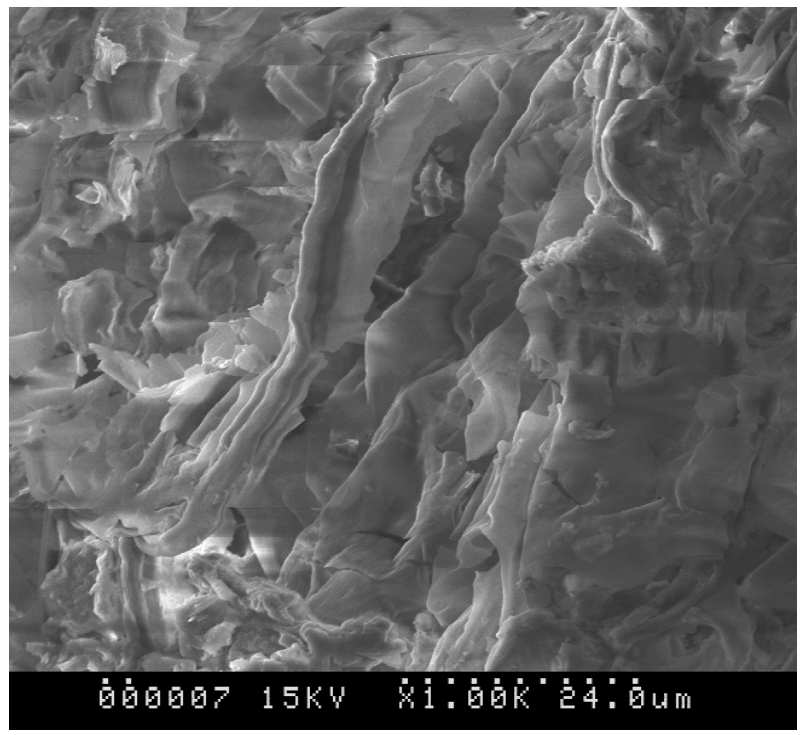

(b)

Figure 1. (a) Micrograph of saprist peat $\leq 425 \mu \mathrm{m}$; (b) Micrograph of fibrist peat $\leq 425 \mu \mathrm{m}$.

\subsection{Peat Crystallography}

The diffractograms (Figure 2(a)) are for saprist peat fractions retained on the $425 \mu \mathrm{m}$ mesh, Figure 2(b) for fibric peat retained on the $425 \mu \mathrm{m}$ mesh and Figure 2(c) for fibric peat fractions $<75 \mu \mathrm{m}$. The diffractograms were similar for all fractions obtained from the dry granulometry for both peat types with no unique or identifiable crystal peaks except for the fraction $<75 \mu \mathrm{m}$ of the fibrist peat, which showed the presence of calcium and silicon oxide. The hump-shaped peak occurring between $18^{\circ}$ and $32^{\circ}$ is a unique characteristic of peat [37].

The saprist peat was more amorphous as no mineral peak was identified compared to the fibrist peat. Known minerals in peat such as quartz and feldspar in a New York woody peat [6] and calcite, kaolinite and quartz in 


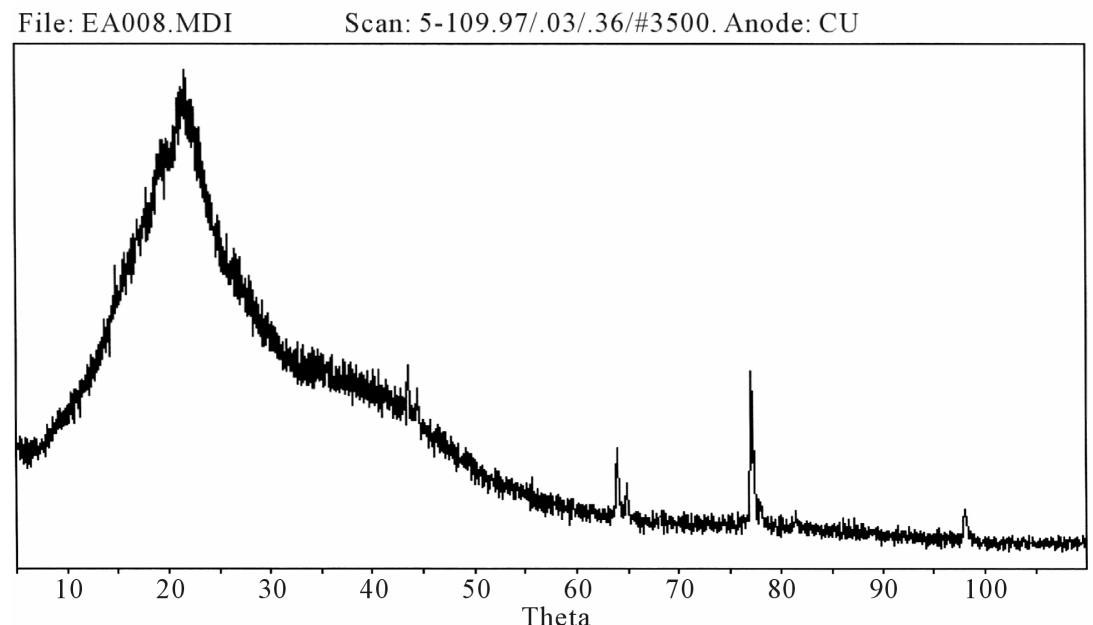

(a)

File: PEATSURF.MDI Scan: 5-109.97/.03/.36/\#3500. Anode: CU

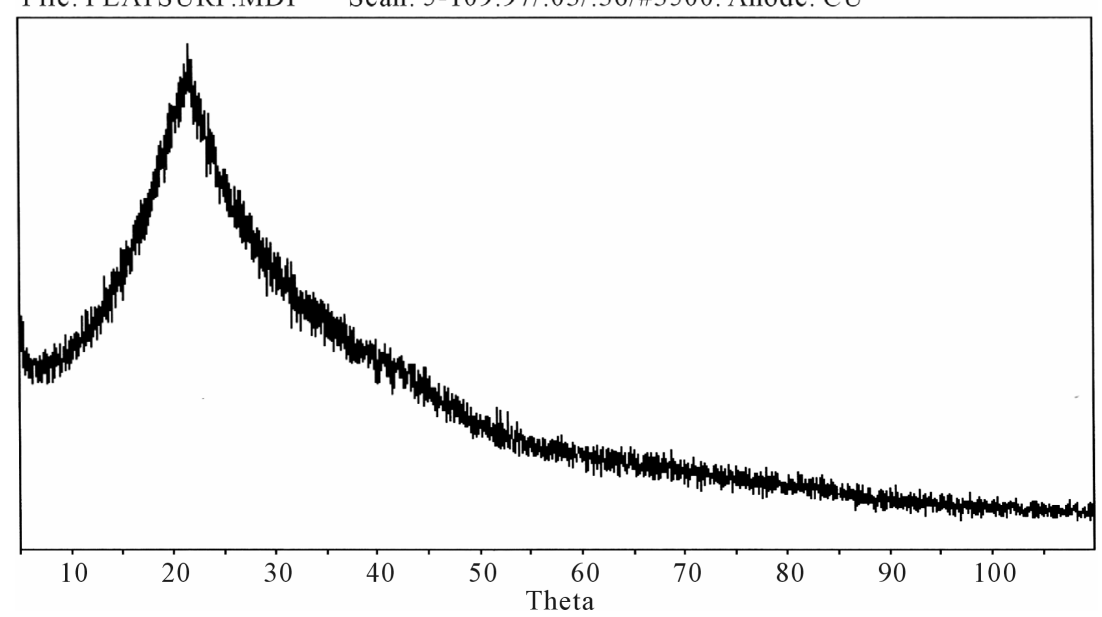

(b)

ID: Second trail!

File: LESS75.MDI Scan: 5-99.95/.03/.36/\#3166. Anode: CU
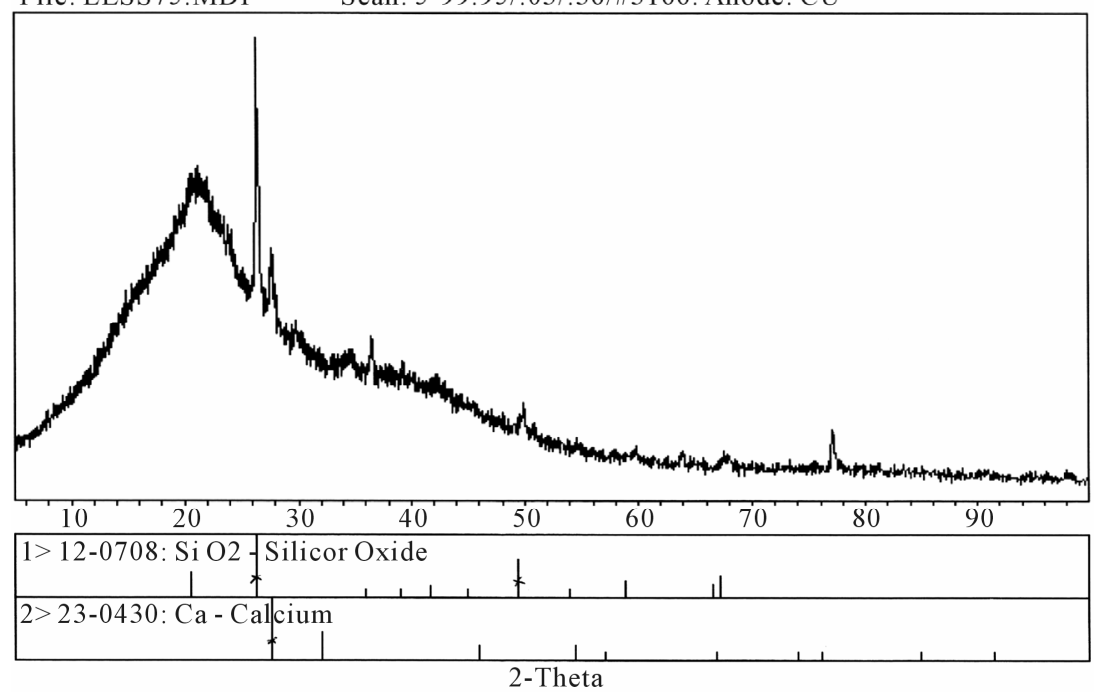

(c)

Figure 2. (a) Diffractograms of saprist peat fractions $\leq 425 \mu \mathrm{m}$; (b) Diffractograms of fibrist peat fractions $\leq 425 \mu \mathrm{m}$; (c) Diffractograms of fibrist peat fractions $<75 \mu \mathrm{m}$. 
an Alder-peat from Poland [38] have been reported, but in this study no known minerals and especially clays were detected by matching the peaks with the JADE software database.

\subsection{Functional Groups}

The FTIR spectra of all size fractions of the saprist peat had similar profiles to the spectra of the fibrist peat fractions $\leq 425 \mu \mathrm{m}$ as shown in Figure 3. Similar spectra suggest a similar chemical composition, thus the chemical composition of the fibrist and saprist peats from the same bog contained similar chemical compounds especially at fractions $\leq 425 \mu \mathrm{m}$. Larger fractions $(>850 \mu \mathrm{m})$ of the fibrist peat showed very broad spectra with fewer distinct peaks.

The probable functional groups present in the peat samples and their corresponding wavenumbers are presented in Table 5. Lange's handbook of Chemistry [39] was the primary source used to identify the probable peaks and where indicated, John Coates in the Encyclopaedia of Analytical Chemistry [40] was also consulted.

The functional groups in the saprist and fine grain fibrist peat appear to be dominated by the presence of organic oxygenated species such as carboxylic acid, alcoholic and phenolic hydroxyls and ethers in addition to amines. All of these groups are comprised of active electron sites in their primary structures and their fluctuating polarization can allow their electrons to be positioned and shared with the incoming metals deficient in electrons. These reactions may governthe peat metal binding chemistry, with complexation of metals being the main path of metal uptake, and ion exchange occurring at a much slower rate.

The measured peaks and their corresponding functional groups are slightly different from values reported in other studies. One of the unique characteristics of this Newfoundland peat is the abundance of amine groups as suggested by the FTIR spectra. The amine group may be particularly important in complexation reactions with a number of metals (such as $\mathrm{Cu}, \mathrm{Pb}, \mathrm{Cd}, \mathrm{Ni}, \mathrm{Zn}$ and $\mathrm{Al}$ ) at a neutral $\mathrm{pH}$ [43].

These differences in composition and orientation of the compounds can be attributed to different parent materials from which the peat is derived, varying climatic and environmental conditions under which the peat is formed, and the different levels of pre-treatments applied to the peat. For example, in one study [38], the peat sample was heated to $350^{\circ} \mathrm{C}$ prior to analytical analysis and this could have altered the chemical composition, while in this study, the pre-treatment consisted of only air drying at room temperature $\left(23^{\circ} \mathrm{C}\right)$. Humic and fulvic acids may be damaged during the harsh processes under which they are extracted from peat and so their FTIR spectra may be only partially comparable with peat FTIR spectra. This study and the work by Orem et al., [41] are two of the very few studies that analyzed peat in close to its natural state.

One study [36] observed the Si-O stretching group $\left(1086 \mathrm{~cm}^{-1}\right)$ in a Brazilian peat. The silicate ion also appeared to be present in the peat in this study at a wavenumber of $915 \mathrm{~cm}^{-1}$. In addition, according to the XRD results (Figure 2(c)) silicon oxide was also present.

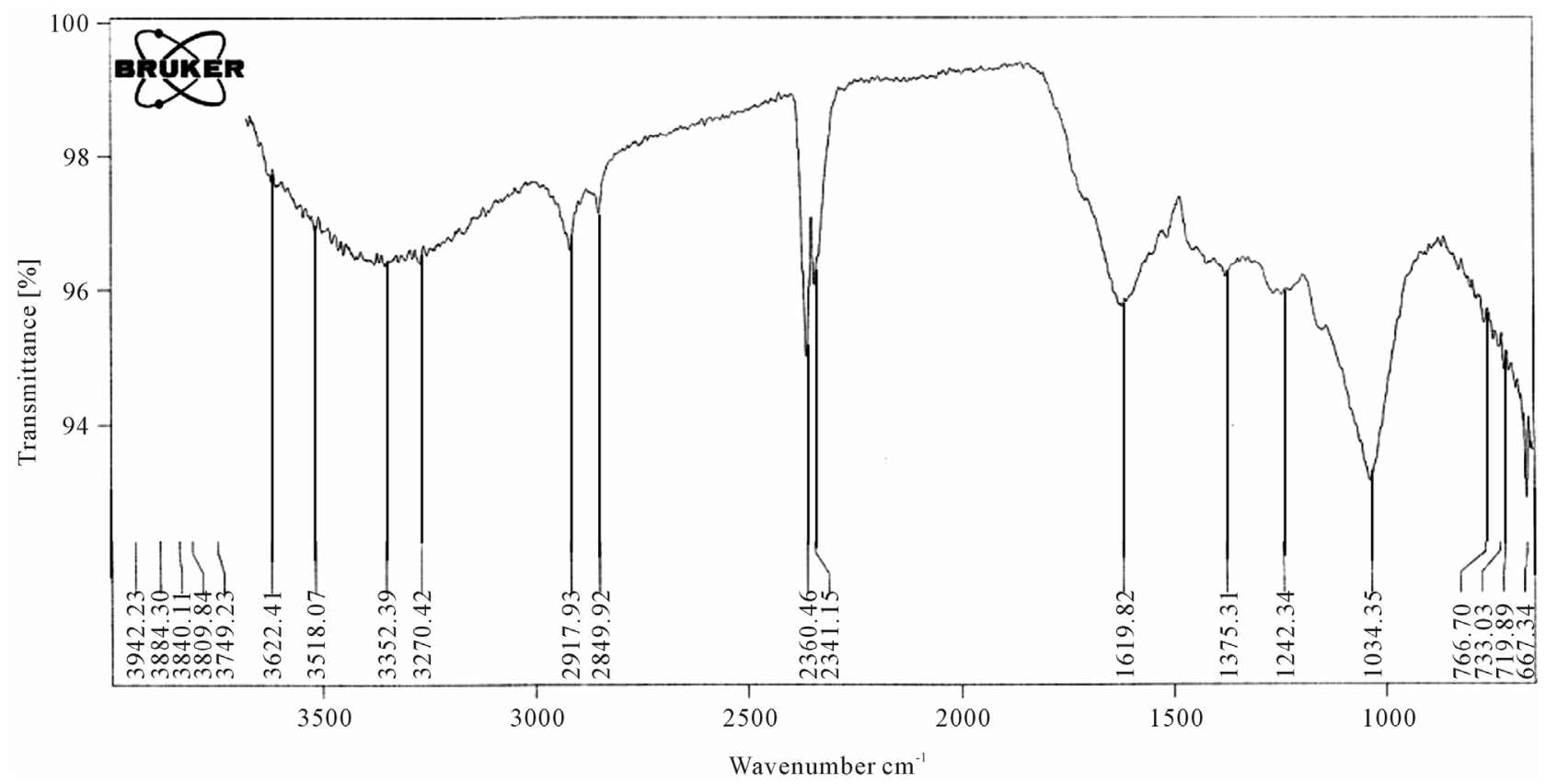

Figure 3. FTIR spectra of saprist peat (fraction $\leq \mathbf{4 2 5} \mu \mathrm{m}$ ) (similar for all fractions $<425 \mu \mathrm{m}$ for both saprist and fibrist peats). 
Table 5. Probable functional groups from FTIR spectra.

\begin{tabular}{|c|c|c|}
\hline Wavenumber $\left(\mathrm{cm}^{-1}\right)$ & Probable Functional Group Assigned Band, $\mathrm{cm}^{-1}$ & Comparable Studies \\
\hline \multirow[t]{2}{*}{3518} & Primary amines (aliphatic) $3550-3300(\mathrm{~m})^{\mathrm{a}}$ & \\
\hline & Secondary amines $3550-3400(w)$ & \\
\hline 3352 & Normal polymeric $\mathrm{OH}$ stretch ${ }^{1}$ & {$[21]$} \\
\hline 3270 & Ammonium ion $3300-3030(s)^{b}$ & \\
\hline 2918 & Carboxylic acids $-\mathrm{CO}_{2} \mathrm{H}, \mathrm{OH}$ stretching $3000-2500$ & {$[41]$} \\
\hline \multirow[t]{2}{*}{2850} & Carboxylic acids $-\mathrm{CO}_{2} \mathrm{H}, \mathrm{OH}$ stretching $3000-2500$ & [41] \\
\hline & Methylene $\left(\mathrm{CH}_{2}\right) \mathrm{C}-\mathrm{H}$ asymmetric/symmetric stretch ${ }^{1}$ & {$[21]$} \\
\hline 2360 & Tertiary amines $\mathrm{R}_{1} \mathrm{R}_{2} \mathrm{R}_{3} \mathrm{NH}^{+} 2700-2250$ & \\
\hline 2341 & Aliphatic CN & \\
\hline \multirow[t]{3}{*}{1620} & Primary amines (aliphatic) $1650-1560(\mathrm{~m})^{\mathrm{a}}$ & \\
\hline & $\mathrm{C}=\mathrm{C}$ conjugated with aromatic ring $1640-1610(\mathrm{~m})$ & {$[41]$} \\
\hline & $\alpha, \beta$ unsaturated carbonyl compounds $1640-1590(\mathrm{~m})$ & \\
\hline \multirow[t]{2}{*}{1412} & Ammonium ion $1430-1390(\mathrm{~s})^{\mathrm{b}}$ & \\
\hline & Vinyl C-H in-plane bend ${ }^{1}$ & \\
\hline 1375 & $=\mathrm{C}\left(\mathrm{CH}_{3}\right)_{2}$ Alkane residues attached to $\mathrm{C} \approx 1380(\mathrm{~m})$ & [41] \\
\hline \multicolumn{3}{|c|}{ Nitro $\mathrm{C}-\mathrm{NO}_{2}$ aromatic $1380-1320(\mathrm{~s})^{\mathrm{c}}$} \\
\hline 1242 & Aromatic ethers, aryl $-\mathrm{O}$ stretch $(\Phi-\mathrm{O}-\mathrm{H})^{1}$ & {$[42]$} \\
\hline 1150 & Tertiary alcohol C-O stretch ${ }^{1}$ & {$[21]$} \\
\hline \multirow[t]{3}{*}{1034} & Hydroxyl O-H primary aliphatic alcohols $1085-1030^{\mathrm{d}}$ & {$[41,42]$} \\
\hline & $-\mathrm{O}-\mathrm{CH}_{3}$ ethers (w-m) c 1030 & \\
\hline & Peroxides -O-O- $1150-1030^{1 \mathrm{e}}(\mathrm{m}-\mathrm{s})$ Alkyl $[41,42]$ & \\
\hline 915 & Silicate ion ${ }^{1}$ & \\
\hline 845 & Nitro $\mathrm{C}-\mathrm{NO}_{2}$ aromatic $865-835^{\mathrm{c}}$ & \\
\hline 825 & Peroxides -O-O- $900-830(w)^{\mathrm{e}}$ & \\
\hline 767 & $-\mathrm{CH}_{2}$ - Rocking vibration & \\
\hline 720 & Saturated $\mathrm{CH}_{2}{ }^{\mathrm{C}} 720$ & {$[42]$} \\
\hline 667 & Hydroxyl O-H primary aliphatic alcohols $700-600^{\mathrm{d}}$ & \\
\hline
\end{tabular}

\footnotetext{
${ }^{1}$ John Coates in Encyclopedia of Analytical Chemistry; ${ }^{a}$ primary amine bands at 3550 - 3300 and 1650 - 1560 ; ${ }^{b}$ ammonium ion bands at $3300-3030$ and $1430-1390$; ${ }^{c}$ nitro $\mathrm{C}-\mathrm{NO}_{2}$ aromatic bands at $1380-1320$ and $865-835$; ${ }^{\mathrm{d}}$ primary aliphatic alcohols bands at $1085-1030$ and $700-600$; ${ }^{\mathrm{e}}$ peroxide bands at $1150-1030$ and $900-830$.
}

Analysis of the ${ }^{13} \mathrm{C}$ NMR spectra as shown in Figure 4 (similar for all other fractions for both peat types), for the fraction $\leq 425 \mu \mathrm{m}$ supported the functional groups identified by the FTIR spectra as shown in Table 6 .

\section{Conclusions}

Characterization of a saprist peat was undertaken as a prelude to its evaluation as an adsorbent for removing metals from wastewaters. The CEC $(70 \mathrm{meq} / 100 \mathrm{~g})$ was higher than that of the poorly humified peat ( $45 \mathrm{meq} / 100 \mathrm{~g}$ ) making the highly humified peat a better cation exchanger. Although the metal content of the fibrist peat was greater this could have been due to its closer contact to the upper layer of the bog and exposure to windblown transport. The ash content of the fibrist peat was almost twice that of saprist peat, which might be due to the different zones of formation and accumulation of inorganic materials such as silicon oxide at the upper layer of the bog. 
Peat

Probe: MAS-HPC-1H

Experiment: $13 \mathrm{C}\{1 \mathrm{H}\}$ CPMAS

Sample: dry peat

Spinning Rate: $20 \mathrm{kHz}$

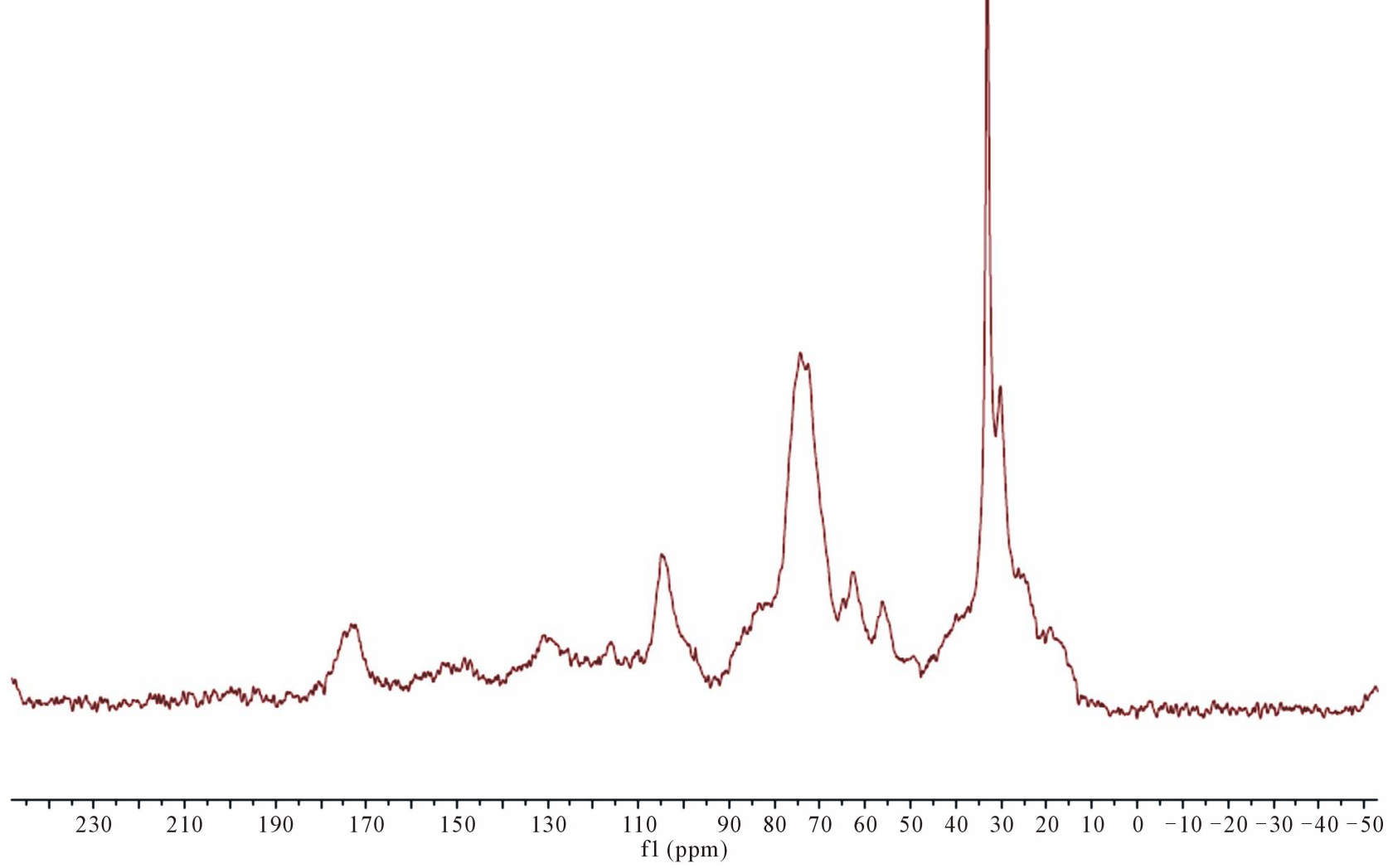

Figure 4. NMR spectra of saprist peat (fraction $\leq 425 \mu \mathrm{m}$ ) (similar for all other fractions for saprist and fibrist peats of fractions $<425 \mu \mathrm{m}$ ).

Table 6. Probable functional groups from ${ }^{13} \mathrm{C}$ NMR spectra of saprist peat.

\begin{tabular}{ccc}
\hline $\begin{array}{c}\text { Chemical shift } \\
\text { range }(\mathrm{ppm})\end{array}$ & Probable functional groups & Similar studies \\
\hline $18.05-40.06$ & $\mathrm{CH}_{3}$ (in long polymeric chains) & {$[44-46]$} \\
& Amine Carbon, Alcohol, ethers, & {$[44-47]$} \\
$56.28-84.15$ & methoxyl & \\
& Phenol, N-substituted aromatic & {$[44,46]$} \\
$100.37-129.43$ & Carboxyl, amide, esters & {$[44,46,47]$} \\
\hline
\end{tabular}

The chemistry of metal binding in the two peat types might be different with the poorly humified peat being more influenced by inherent inorganic compounds present, a fact supported by the detection of silicon oxide $\left(\mathrm{SiO}_{2}\right)$ in the XRD spectrum of fraction $<75 \mu \mathrm{m}$. With the absence of clay minerals and any known inorganic substances in the highly humified peat (compared to the poorly humified peat sample), any metal uptake in this peat type may be due to the functional group chemistry and the readily available exchangeable cations initially present in this amorphous material. Since the highly humified peat was more homogeneous in physical nature, it might be easier to study the peat metal binding chemistry from this peat type.

\section{Acknowledgments}

The authors appreciate the financial support from NSERC and MUN and are grateful to Mr. R. Traverse of Traverse Gardens, Torbay, for supplying the peat soils. Also appreciated are the contributions of MUN laboratory technicians, Ms L. Men and Ms. A. Hillier (SEM) of the Biological Science Department, and Ms. H. Gillespie (XRD) and Ms. P. King (ICP-MS) of the Earth Science Department and Dr Celine Schneider (NMR) of Chemistry Department.

\section{REFERENCES}

[1] Y. Couillard, M. Courcelles, A. Cattaneo and S. Wunsam, "A Test of Integrity of Metal Records in Sediment Cores Based on the Documented History of Metal Contamination in Lac Dufault (Québec, Canada)," Journal of Paleo- 
limnology, Vol. 32, No. 2, 2004, pp. 149-162. doi:10.1023/B:JOPL.0000029429.13621.68

[2] R. Parker and C. Dumaresq, "Effluent Characterization, Water Quality Monitoring and Sediment Monitoring in the Metal Mining EEM Program," Water Quality Research Journal of Canada, Vol. 37, No. 1, 2002, pp. 219228.

[3] G. Annadurai, R.-S. Juang and D.-J. Lee, "Adsorption of Heavy Metals from Water Using Banana and Orange Peels," Water Science and Technology, Vol. 37, No. 1, 2002, pp. 185-190.

[4] M. A. Zarraa, "Study on the Removal of Chromium (VI) from Wastes Solutions by Adsorption onto Sawdust in Vessels," Advertising Science and Technology, Vol. 12, No. 2, 1995, pp. 129-138.

[5] B. Coupal and J.-M. Lalancette, "The Treatment of Wastewaters with Peat Moss," Water Research, Vol. 10, No. 12, 1976, pp. 1071-1076. doi:10.1016/0043-1354(76)90038-5

[6] P. R. Bloom and M. B. McBride, "Metal Ion Binding and Exchange with Hydrogen Ions in Acid-Washed Peat," Soil Science Society of America Journal, Vol. 43, No. 4, 1979, pp. 687-692. doi:10.2136/sssaj1979.03615995004300040012x

[7] G. Blanachard, M. Muanaye and G. Martin, "Removal of Heavy Metals from Water by Means of Natural Zeolites," Water Research, Vol. 18, No. 12, 1984, pp. 1501-1507. doi:10.2136/sssaj1979.03615995004300040012x

[8] S. E. Bailey, T. J. Olin, R. M. Bricka and D. D. Adrian, "A Review of Potentially Low-Cost Sorbents for Heavy Metals," Water Research, Vol. 33, No. 11, 1999, pp. 2469-2479. doi:10.1016/S0043-1354(98)00475-8

[9] C. B. Dissanayake and S. V. R. Weerasooriya, "Peat as a Metal-Trapping Material in Purification of Industrial Effluents," International Journal of Environmental Studies, Vol. 17, No. 3, 1981, pp. 233-238. doi:10.1080/00207238108709912

[10] S. Babel and T. A. Kurniawan, "Low-Cost Adsorbents for Heavy Metals Uptake from Contaminated Water: A Review," Journal of Hazardous Materials, Vol. 97, No. 1-3, 2003, pp. 119-243.

[11] US Market Information, "Personal Communication," 2008.

[12] USGS 2006a, Mineral Commodity Summaries (accessed 10 November 2008). http://minerals.usgs.gov/minerals/pubs/mcs/

[13] USGS 2006b, Mineral Commodity Summaries (accessed 10 November 2008). http://miinerals.usgs.gov/minerals/pubs/mcs/

[14] USGS 2006c, Mineral Commodity Summaries (accessed 10 November 2008). http://minerals.usgs.gov/minerals/pubs/mcs/

[15] J. I. Pérez, E. Hontoria, M. Zamorano and M. A. Gómez, "Wastewater Treatment Using Fibrist and Saprist Peat: A Comparative Study," Journal of Environmental Science and Health A, Vol. 40, No. 5, 2005, pp. 1021-1032.

[16] I. Twardowska, J. Kyziol, T. Goldrath and Y. Avnimelech, "Adsorption of Zinc onto Peat from Peatlands of Poland and Israel," Journal of Geochemical Exploration, Vol. 66, No. 1-2, 1999, pp. 387-405.
[17] A. Martinez-Cortizas, X. Ponteveda-Pombai, E. GarciaRodeja, J. C. Nóvoa-Muñoz and W. Shotyk, "Mercury in a Spanish Peat Bog: Archive of Climate Change and Atmospheric Metal Deposition," Science, Vol. 284, No. 5416, 1999, pp. 939-942.

doi:10.1126/science.284.5416.939

[18] E. Bohlin, M. Hämäläinen and T. Sunden, "Botanical and Chemical Characterization of Peat Using Multivariate Methods," Soil Science, Vol. 147, No. 4, 1989, pp. 252263. doi:10.1097/00010694-198904000-00004

[19] B. Nordén, E. Bohlin, M. Nilsson, A. Albano and C. Röckner, "Characterization of Particle Size Fractions of Peat: An Integrated Biological, Chemical, and Spectroscopic Approach," Soil Science, Vol. 153, No. 5, 1992, pp. 382-396. doi:10.1097/00010694-199205000-00006

[20] P. J. Spedding, "Peat," Fuel, Vol. 67, No. 7, 1988, pp. 883-900. doi:10.1016/0016-2361(88)90087-7

[21] J. Niemeyer, Y. Chen and J.-M. Bollag, "Characterization of Humic Acids, Composts, and Peat by Diffuse Reflectance Fourier-Transform Infrared Spectroscopy," Soil Science Society of America Journal, Vol. 56, No. 1, 1992, pp. 135-140. doi:10.2136/sssaj1992.03615995005600010021x

[22] A. Baran, "Characterization of Carex Peat Using Extinction Values of Humic Acids," Bioresource Technology, Vol. 85, No. 1, 2002, pp. 99-101. doi:10.1016/S0960-8524(02)00072-X

[23] H. Li, L. E. Parent, A. Karam and C. Tremblay, "Potential of Sphagnum Peat for Improving Soil Organic Matter, Water Holding Capacity, Bulk Density and Potato Yield in a Sandy Soil," Plant and Soil, Vol. 265, No. 1-2, 2004, pp. 355-365.

[24] D. Gondar, R. Lopez, S. Fiol, J. M. Antelo and F. Arce, "Characterization and Acid-Base Properties of Fulvic and Humic Acids Isolated from Two Horizons of an Ombrotrophic Peat Bog," Geoderma, Vol. 126, No. 3-4, 2005, pp. 367-374.

[25] S. S. Fong and M. Mohamed, "Chemical Characterization of Humic Substances Occurring in the Peats of Sarawak, Malaysia," Organic Geochemistry, Vol. 38, No. 6, 2007, pp. 967-976. doi:10.1016/j.orggeochem.2006.12.010

[26] P. Burba, A.-M. Beer and J. Lukanov, "Metal Distribution and Binding in Balneological Peats and Their Aqueous Extracts," Fresenius' Journal of Analytical Chemistry, Vol. 37, No. 4, 2001, pp. 419-425. doi: $10.1007 / \mathrm{s} 002160100810$

[27] Y. S. Ho, D. A. J. Wase and C. F. Forster, "Batch Nickel Removal from Aqueous Solution by Sphagnum Moss Peat," Water Research, Vol. 29, No. 5, 1995, pp. 1327 1332. doi:10.1016/0043-1354(94)00236-Z

[28] R. H. Crist, J. R. Martin, J. Chonko and D. R. Crist, "Uptake of Metals on Peat Moss: An ion Exchange Process," Environmental Science \& Technology, Vol. 30, No. 8, 1996, pp. 2456-2461. doi:10.1021/es950569d

[29] L. Ringqvist, A. Holmgren and I. Öborn, "Poorly Humified Peat as an Adsorbent for Metals in Wastewater," Water Research, Vol. 36, No. 9, 2002, pp. 2394-2404. doi:10.1016/S0043-1354(01)00430-4

[30] R. H. Kadlec and G. A. Keoleian, "Metal Ion Exchange 
on Peat in Peat and Water," Elsevier Applied Science Publishers Ltd., Amsterdam, 1986, pp. 61-93.

[31] I. Kuziemska and B. Quant, "Peat as a Sorbent for Heavy Metal Removal from Water and Wastewater," Proceedings of Green, the International Symposium on Geotechnics Related to Environment 2, Wolverhampton, 28 June1 July 1998, pp. 308-312.

[32] F. Pollet, C. M. Lane, F. Gover and J. H. McKillop, "Peat Resources of Newfoundland," Mineral Resources Report, No. 2, 1968, pp. 4-5.

[33] ASTM, "Annual Books of ASTM Standards, Section 4: Construction," ASTM, West Conshohocken, 2006.

[34] B. H. Sheldrick, Ed., "Analytical Methods Manual," Agriculture and Agri-Food Canada, Ottawa, 1984.

[35] T. J. Malterer, E. S. Verry and J. Erjavec, "Fiber Content and Degree of Decomposition in Peats: Review of National Methods," Soil Science Society of America Journal, Vol. 56, No. 4, 1992, pp. 1200-1211. doi:10.2136/sssaj1992.03615995005600040033x

[36] S. Bozkhurt, M. Lucisano, L. Moreno and I. Neretnieks, "Peat as a Potential Analogue for the Long-Term Evolution in Landfills," Earth-Science Reviews, Vol. 53, No. 1-2, 2001, pp. 95-147. doi:10.2136/sssaj1992.03615995005600040033x

[37] L. P. C. Romăo, J. R. Lead, J. C. Rocha, L. C. de Oliveira, A. H. Rosa, A. G. R. Mendonça and A. de S. Ribeiro, "Structure and Properties of Brazilian Peat: Analysis by Spectroscopy and Microscopy," Journal of the Brazilian Chemical Society, Vol. 18, No. 4, 2007, pp. 714-720. doi:10.1590/S0103-50532007000400008

[38] I. Twardowska and J. Kyziol, "Binding and Chemical Fractionation of Heavy Metals in Typical Peat Matter," Fresenius Journal of Analytical Chemistry, Vol. 354, No. 5-6, 1996, pp. 580-586.

[39] N. A. Lange and J. G. Speight, "Lange's Handbook of Chemistry," 16th Edition, McGraw-Hill Inc., Boston, 2005.

[40] J. Coates, "Interpretation of Infrared Spectra: A Practical Approach," In: R. A. Meyers, Ed., Encyclopedia of Analytical Chemistry, John Wiley \& Sons, Hoboken, 2000, pp. $10815-10837$.

[41] W. H. Orem, S. G. Neuzil, H. E. Lerch and C. B. Cecil, "Experimental Early-Stage Coalification of a Peat Sample and a Peatified Wood Sample from Indonesia," Organic Geochemistry, Vol. 24, No. 2, 1996, pp. 111-125. doi:10.1016/0146-6380(96)00012-5

[42] R. R. E. Artz, S. J. Chapman, A. H. J. Robertson, J. M. Potts, F. Laggoun-Défarge, S. Gogo, L. Comot, J. R. Disnar and A. J. Francez, "FTIR Spectroscopy Can Be Used as a Screening Tool for Organic Matter Quality Regenerating Cutover Peatlands," Soil Biology \& Biochemistry, Vol. 40, No. 2, 2008, pp. 515-527. doi:10.1016/j.soilbio.2007.09.019

[43] S. E. Cabaniss, "Quantitative Structure-Property Relationships for Predicting Metal Binding by Organic Ligands," Environmental Science \& Technology, Vol. 42, No. 14, 2008, pp. 5210-5216. doi:10.1021/es7022219

[44] C. M. Preston, D. E. Axelson, M. Lévesque, S. P. Mathur, H. Dinel and R. L. Dudley, "Carbon-13 NMR and Chemical Characterization of Particle-Size Separates of Peats Differing in Degree of Decomposition," Organic Geochemistry, Vol. 14, No. 4, 1989, pp. 393-403. doi:10.1016/0146-6380(89)90005-3

[45] J. A. Baldrock, J. M. Oades, A. G. Waters, X. Peng, A. M. Vassallo and M. A. Wilson, "Aspects of the Chemical Structure of Soil Organic Materials as Revealed by SoliState 13C NMR Spectroscopy," Biogeochemistry, Vol. 16, No. 1, 1992, pp. 1-42.

[46] J.-D. Mao, W.-G. Hu, K. Schmidt-Rohr, G. Davies, E. A. Ghannour and B. Xing, "Quantitative Characterization of Humic Substances by Solid-State Carbon-13 NMR," Soil Science Society of America Journal, Vol. 64, No. 3, 2000, pp. 873-884. doi:10.2136/sssaj2000.643873x

[47] G. Almendros, H. Knicker and J. Gonzalez-Vila, "Rearrangement of Carbon and Nitrogen forms in Peat after Progressive Thermal Oxidation as Determined by Solid State 13C and 15N-NMR Spectroscopy," Organic Geochemistry, Vol. 34, No. 11, 2003, pp. 1559-1568. doi:10.1016/S0146-6380(03)00152-9 